\title{
Bioecology of Nephopterygia austeritella (Lep.: Pyralidae), a potential biological control agent of Prosopis farcta (Fabaceae) in central Iran
}

\author{
A. Mohammadi-Khoramabadi*, H. Alipanah², S. Belokobylskij ${ }^{3}$ \\ and M.R. Nematollahi ${ }^{4}$
}

\begin{abstract}
Summary Prosopis farcta (Fabaceae) is a native and common perennial weed plant in Iran. In search of environmental-friendly control methods against $P$. farcta, we discovered the seed feeder moth Nephopterygia austeritella (Lepidoptera; Pyralidae) in central Iran and studied its bioecology for the first time from 2008 through 2009. Infestation pattern, larval feeding behaviour, developmental period, seasonal occurrence and the adverse impact of the moth on the reproductive organs of $P$. farcta were investigated. Diagnostic morphological characters of the fifth larval instar of N. austeritella are provided. Two gregarious ectoparasitoids were reared and identified as Apanteles subcamilla and Phanerotoma leucobasis (Hymenoptera: Braconidae). Mortality rates of the larvae were 3.03 and $13.44 \%$ in 2008 and 2009, respectively. Larvae destroyed $29.6-38.4 \%$ of the pods of their host plants. The potential of N. austeritella as an efficient biological control agent in IPM programs against $P$. farcta is discussed.
\end{abstract}

Additional keywords: mesquite, impact, parasitoid, pest, seed, weed.

\section{Introduction}

Syrian mesquite, Prosopis farcta (Banks \& Solander) (Fabaceae), is a perennial, thorny, xerophilous and salt-tolerant shrub which is widely spread from India to Algeria between latitudes $\mathrm{Ca} 10^{\circ}$ (in Yemen) and $50^{\circ}$ in Kazakhstan (Bazzaz, 1973; Bisby et al., 2011). Prosopis farcta is an economically multifaceted plant. It has been regarded as a useful plant for fixation of nitrogen and the production of nutrient-rich pods and foliage, especially in saline and arid environments and serves as a source of fodder in many countries (Said et al., 2002; Dogan et al., 2004; Omidi et al., 2012). However, special biological attributes of $P$. farcta have increased the competitive and prevalent properties of this weed

\footnotetext{
Department of Plant Production, College of Agriculture and Natural Resources of Darab, Shiraz University, Darab, Iran

2 Department of Insect taxonomy, Iranian Research Institute of Plant Protection, Tehran, Iran

${ }^{3}$ Zoological Institute of Russian Academy of Sciences, St. Petersburg, Russia

${ }^{4}$ Department of Plant Protection, Isfahan Research Center for Agriculture and Natural Resources, P.O.Box 81785-199, Isfahan, Iran

* Corresponding author: Mohamadk@Shirazu.ac.ir
}

in orchards (e.g. olive and temperate-zone fruits) and fields (e.g. sesame and vegetables) (Johnson, 1983; Pasiecznik et al., 2004; Sertkaya et al., 2005; Qasem, 2007) such as its deep rhizobia-symbiont root system (Bazzaz, 1973; Canadell et al., 1996; Atomov and Aktoklu, 2007; Fterich et al., 2011) that propagates through both long-lived seeds and rhizome buds (Qasem, 2007). These features allow $P$. farcta to produce enormous and durable dense stands and quickly become a dominant weed in agroecosystems. Prosopis farcta is also a host of witches' broom disease which is the most destructive disease of alfalfa in Iran (Esmailzadeh-Hosseini et al., 2011).

In order to control P. farcta and other species of the same genus in agricultural ecosystems, efforts were made to preserve the beneficial attributes of these plants while limitting their dispersal and competition with agricultural crops. To date, soil solarisation, mechanical methods and chemical control (Qasem, 2007) have failed to effectively control $P$. farcta. By contrast, biological agents can be used against $P$. farcta in an integrated management program (Johnson, 1983; Mc Kay and Gandolfo, 2007; Qasem, 
2007). Among the insects associated with $P$. farcta, the seed beetle Caryedon angeri Semenov (Coleoptera: Chrysomelidae) is reported as the most harmful agent attacking the reproductive organs of $P$. farcta in the Middle East (Johnson, 1983; Sertkaya et al., 2005). Caryedon angeri usually infests Acacia spp. and P. farcta, but there are concerns about its tendency to attack non-target species, such as groundnut (Arachis hypogaea L. (Fabaceae) (Bagheri-Zenous, 1992; Anton and Delobel, 2004). It is argued that C. angeri is not a good candidate for the biological control of the weed (Sertkaya et al., 2005). Parasitoid braconid wasps attacking lepidopteran species of the families Lycaenidae, Geometridae and Gelechiidae that feed on $P$. farcta were recorded by Halperin (1986).

Recent observations on $P$. farcta shrubs in southern Iran revealed that the pyralid moth Nephopterygia austeritella Amsel (Lepidoptera: Pyralidae, Phycitinae) can feed on the pods of $P$. farcta (Alipanah et al., 2012). Nephopterygia austeritella has been recorded from Sudan (Amsel, 1965) to the Canary Islands (Spain), Egypt (Asselbergs, 2009) and Iran (Alipanah et al., 2012). This work was intended to study the bioecology of $N$. austeritella under natural conditions in central Iran and its negative impact on the reproductive organs of $P$. farcta.

\section{Materials and methods}

\section{Infestation by the herbivore}

The infestation of $P$. farcta by $N$. austeritella was studied in an abandoned orchard of approximately 10 hectares in Yazd County $\left(31^{\circ} 89^{\prime} \mathrm{N}, 54^{\circ} 36^{\prime} \mathrm{E}, 1230 \mathrm{~m}\right.$ a.s.l.), Yazd province, Iran. A map showing the study site is illustrated in Figure 1. Sampling was performed according to the $P$. farcta phenology, from May (early spring coinciding with leaf formation) to November (late autumn during leaf fall) at 10-15 day intervals, during 2008 and 2009. A random sample of 100 pods was made from branches of $P$. farcta. The sampled pods were then transferred to the laboratory where they were dissected with a sharp knife. The number of infested pods, larvae and externally parasitized larvae (as in Figure 2B-F) were recorded. The phenology of the host plant was recorded in each sampling date.

\section{Infestation pattern}

Infestation pattern of pods of $P$. farcta by $N$. austeritella was examined in a sample taken on 27 June 2009 from Yazd County area coinciding with the late emergence of adults (Figure 3 ). Fifty stems of $P$. farcta (one stem in each bush) were randomly selected and all pods (114), the number of infested pods and larva(e) within each pod (Figure $2 \mathrm{~B}-\mathrm{C}$ ) were recorded. Infestation pattern of pods was calculated based on single or multiple larvae in each pod.

\section{Description of larval instars}

Larval instars were documented by determining the distance between the external extreme of the ocelli as the breadth of the head capsule of the larvae (Freitas, 1993). The body length of the larvae was measured from the anterior edge of the anteclypeus to the posterior edge of the anal plate. These data were used for determining the larval instars of $N$. austeritella using Dyar's rule. All measurements were made using a calibrated ocular micrometer of an Olympus stereomicroscope on 5-10 larvae collected from the study area of Yazd County in each sampling date. The larvae are described here for the first time. The fifth larval instar was described and illustrated in detail to distinguish it from other species of the family Pyralidae. Their mouthparts were dissected following the methods of Godfrey (1972), and the setal nomenclature follows that of Hasenfuss and Kristensen (2003).

\section{Impact of $N$. austeritella on pods of $P$. farcta}

Natural impact of $N$. austeritella on $P$. farcta pods was evaluated in March 2008 and 2009 (late winter) coinciding with the end of annual growing period of the plant at three areas in central Iran: Abarkouh coun- 


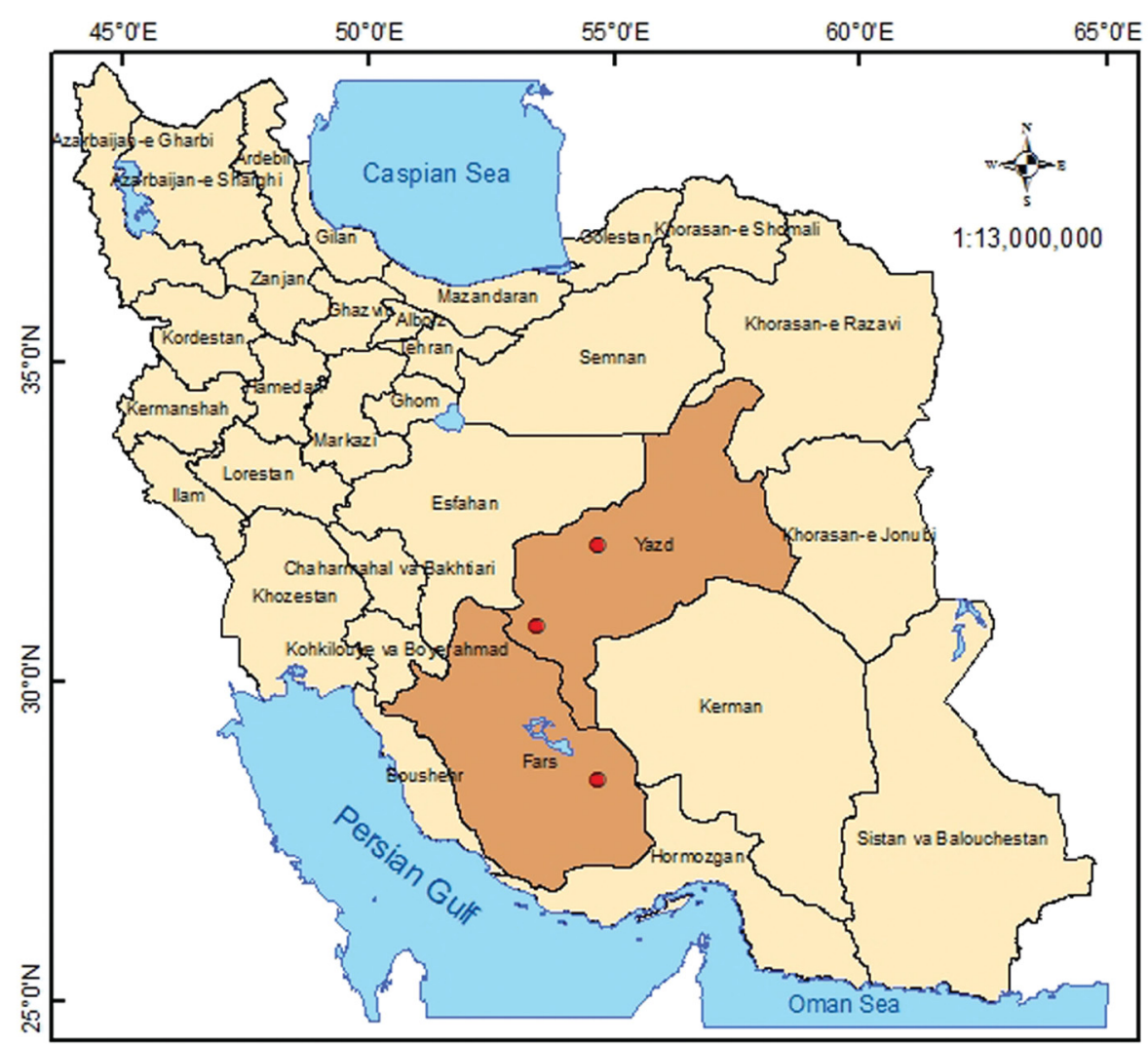

Figure 1. Map of sampling areas of Nephopterygia austeritella in central Iran.

ty, Yazd province $\left(31^{\circ} 12^{\prime} \mathrm{N}, 5^{\circ} 28^{\prime} \mathrm{E}, 1510 \mathrm{~m}\right.$ a.s.l.), Darab county, Fars province $\left(28^{\circ} 47^{\prime} \mathrm{N}\right.$, 54 $33^{\prime} \mathrm{E}, 1100 \mathrm{~m}$ a.s.l.) and Yazd county, Yazd province, Iran (Figure 1). For this purpose, several bushes of $P$. farcta were randomly selected and all pods of a single branch were selected to provide a sample of 100 pods. There were six replicates (totally 600 pods) in each area. The pods were then dissected in the laboratory and the rate of damaged pods was calculated.

\section{Natural enemies of $N$. austeritella}

We inspected the infested pods of $P$. farcta for larval parasitoids of N. austeritella in the study area of Yazd County. Anaesthetized or with observable parasitoid larvae were transferred to the laboratory and kept in ventilated plastic rearing boxes. Adult par- asitoids were collected and identified by the third author (Tobias et al., 1986; Van Achterberg, 1990).

\section{Results}

\section{General biology}

The first adults of $N$. austeritella emerged in late May (Figures $2 \mathrm{~A}$ and 3 ) and their appearance lasted until mid-June. This period was synchronized with the first flowering period of $P$. farcta, which began from early May, in the studied areas, when the formation of green fruits occurs. The females laid their eggs singly on the surface of the young green pods of the host plant (Figure 2B).

The first larval instar ate the egg chorion immediately after hatching and it then 

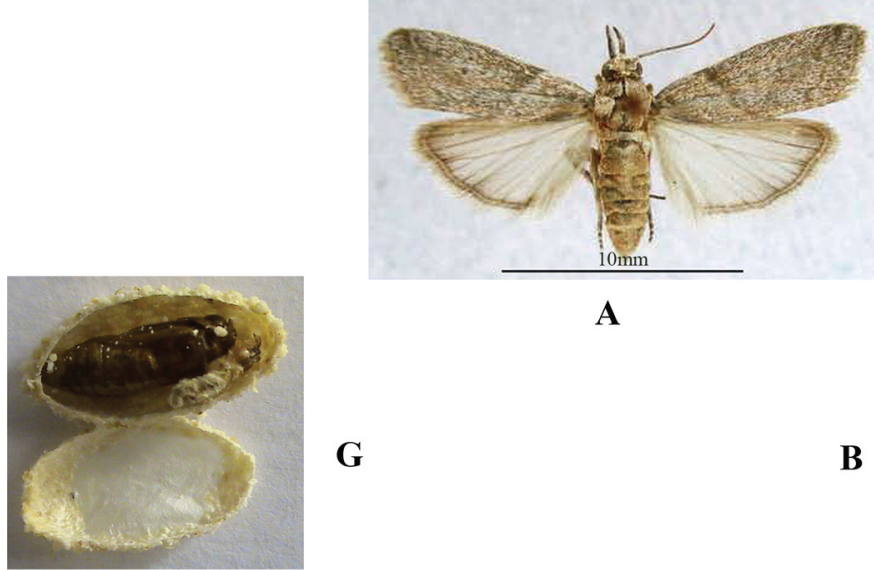

A

G

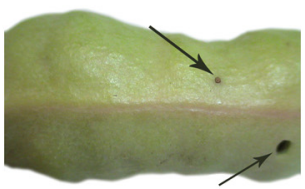

B

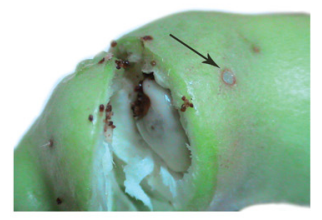

C

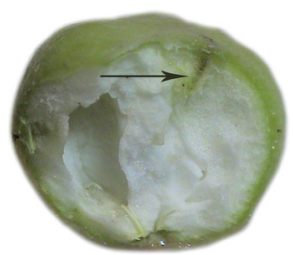

$\mathbf{E}$

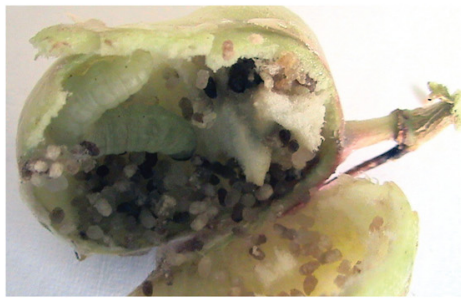

D

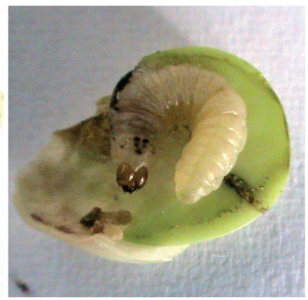

Figure 2. Life cycle of Nephopterygia austeritella. The adult female (A) lays its eggs on the surface of a green pod (B), the first instar larva moves to the seed in pod (C), the second instar larva feeds within the seed (D), the larva in the third and following instars completely destroys the mesocarp and seeds of the ripening pod (E), the larva makes a hole to exit from the destroyed pod (the above and below arrow indicates the position of egg and the exiting hole on the pod, respectively) (F), The last instar larva pupates within an oval silken cocoon (G).

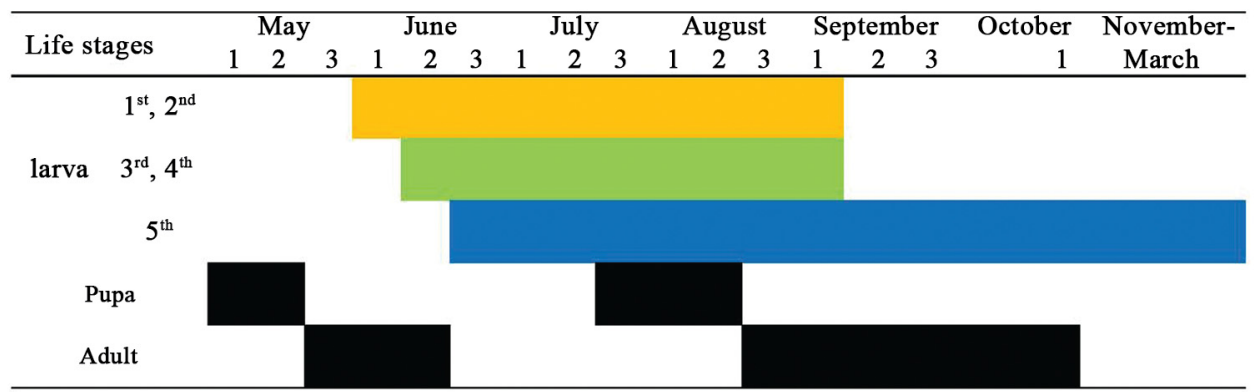

Figure 3. Phenology of Nephopterygia austeritella on the Syrian mesquite, Prosopis farcta, in central Iran.

(c) Benaki Phytopathological Institute 
penetrated into the pod just beneath the egg and entered the seed (Figure $2 \mathrm{C}$ ) by chewing a tunnel through the cotyledon. The first and second instars fed on the seed (Figure 2D-E) and destroyed it completely. These two instars were observed from early June to early September (Figure 3). Third larval instar appeared in mid-June, when they left the remains of the seed to feed on the other seeds including mesocarp (internal tissues of the pod), leaving the outer shell intact (Figure 2E). To complete the larval stage, the larva had to exit the pod by making a hole (Figure 2F). After entering another pod, the larva sealed the entrance with silk fibres. Each pod usually contains one larva, although up to two larvae were rarely seen in the same pod. Movement of the larvae from one pod to another was facilitated by silk fibres. Pupation began from late June, when the last larval instar abandoned the damaged pod and descended on the surface of the soil (Figure 3). In the rearing boxes, the last larval instar spun silken cocoons 10-13 mm in length (Figure 2G), at different heights of the boxes. Adult moths emerged (at $30 \pm 2^{\circ} \mathrm{C}, 20 \pm 5 \%$ R. H.) about two weeks later. Emergence period was long and lasted from mid-August to mid-September in 2008 and from mid-August to early October in 2009 (Figure 3). This was the second emergence period, which indicates the second generation of $N$. austeritella.

Our sampling in late autumn and winter showed that no larvae existed in the pods of $P$. farcta at that time. The pods had very hard outer shells and could be hardly broken by larvae. Therefore, it may be that N. austeritella overwinters as a full-grown fifth larval instar within a cocoon outside the pod of P. farcta.

\section{Infestation pattern}

Counting the number of larvae (first or second instars) within a sample taken on 27 June 2009 showed that 65.91, 20.45, 11.36 and $2.27 \%$ of pods had one to four larvae, respectively.

\section{Description of the immature stages of $N$. austeritella}

Based on the measurement of the head capsule, the insect has five larval instars (Table 1) as follows:

\section{First larval instar}

Pale yellow to creamy white, with light brownish head and prothoracic plate light orange posteriorly.

\section{Second and third instars}

Nearly in the same colour as the first one.

\section{Fourth larval instar}

Head, thoracic plate, body, thoracic legs, prolegs and anal plate of the same colour and pattern as in the fifth larval instar.

\section{Fifth larval instar in detail}

Colour: Head light brownish, with pale mottled pattern, a very short coronal suture and an ellipse of six ocelli. Ocellar area dark brown, forming dark lateral patch encompassing ocelli 1 to 5 ; lower part of gena close to antennal region with a dark brown patch; anteclypeal region, frontal and adfrontal sclerites pale brown; labrum dark brown, notch edged with dark brown to black; mandible light brown and edged with brown distally (Figure 4E); spinneret and labial palpi light brown; antennal segments cream (Figure 4F); body creamy yellow, integument gran-

Table 1. Measurement of head capsule width and body length of larvae of Nephopterygia austeritella in each instar.

\begin{tabular}{l|c|c|c}
\hline Larval instar & Nr of examined larvae & Head capsule width $(\mathrm{mm} \pm \mathrm{SD})$ & Maximum body length $(\mathrm{mm})$ \\
\hline First & 5 & $0.18 \pm 0.02$ & 1.30 \\
Second & 5 & $0.71 \pm 0.02$ & 7.04 \\
Third & 5 & $1.06 \pm 0.06$ & 10.63 \\
Fourth & 6 & $1.19 \pm 0.01$ & 12.75 \\
Fifth & 10 & $1.62 \pm 0.09$ & 14.88 \\
\hline
\end{tabular}




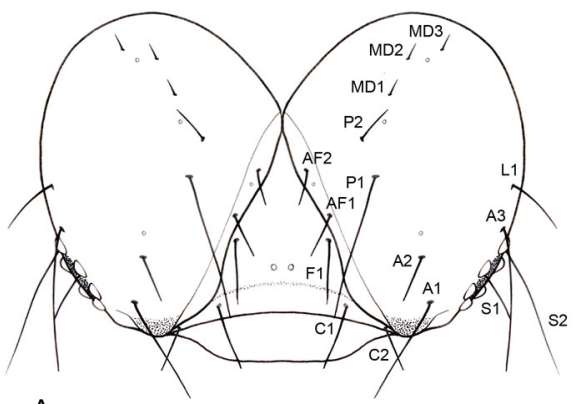

A
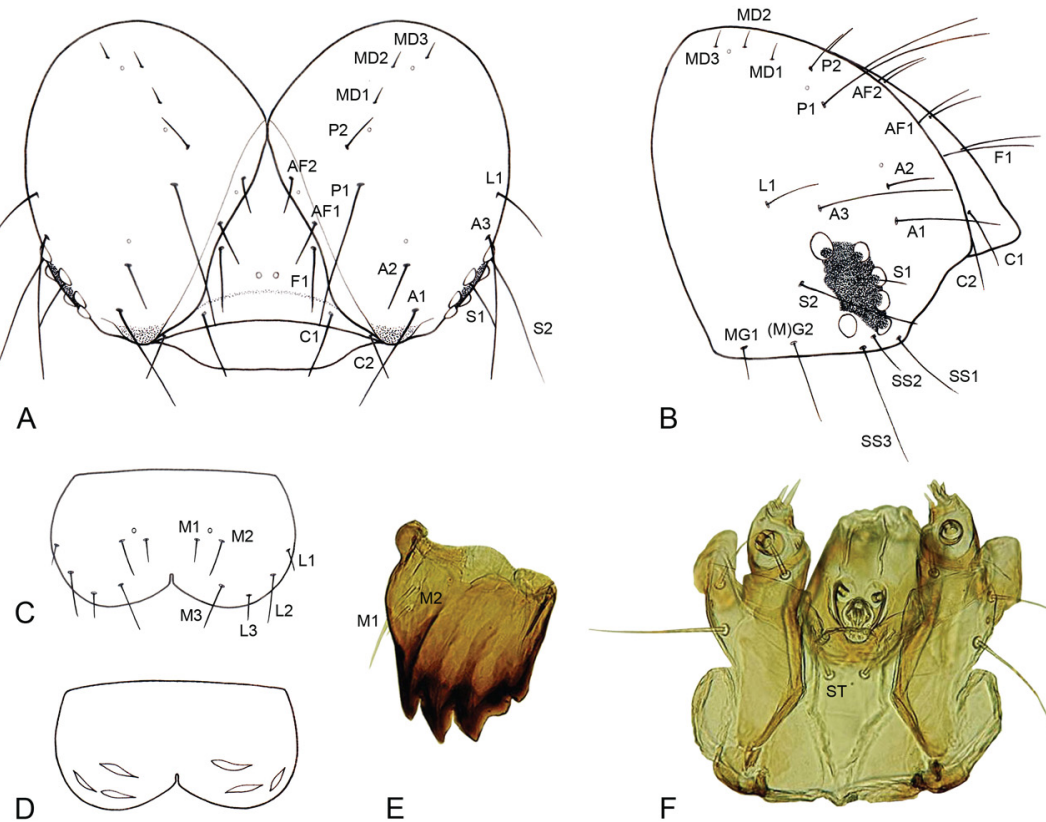

E

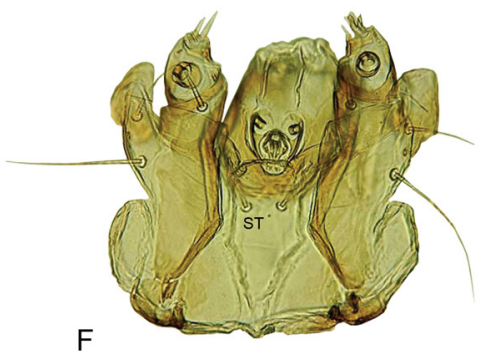

Figure 4. Head structure of the fifth larval instar of Nephopterygia austeritella. A) frontal view, B) lateral view, C) labrum, D) epipharynx, E) right mandible, F) maxillo-labium. Sensillium designations: A, anterior; AF, adfrontal; $C$, clypeal; F, frontal; L, lateral; $M$ (in ( and E designation for labral and mandibular setae); MD, microdorsal; MG, microgenal; P, parietal; S, stemmatal (= ocular, 0); SS, substemmal (= subocular, SO); ST, stipular (in maxillo-labium).

ulose under low magnification; prothoracic plate very slightly darker than the ground colour, with a postero-median notch and a pattern of pale brown markings; thoracic legs yellowish cream with brownish claw (Figure 5B); anal plate creamy yellow; crochets brown; peritremes of spiracles dark.

Chaetotaxy: Head (Figure 4A-F): Frontal sclerite extended to almost four-fifths of head length, the latter slightly more than its breadth at base; adfrontals slightly tapered medially; ocellus 5 slightly extended out of the circumscribed ocellar semicircle; seta P1 almost $4 x$ as long as seta P2; distance between setae AF1 and AF2 nearly equal to distance between setae $\mathrm{P} 1$ and $\mathrm{P} 2$; the length of seta $A 2$ slightly less than the length of seta $A 3$; seta $A 3$ almost $4 x$ as long as seta $A 1$; seta $S 2$ more than $3 \times$ as long as seta S1.

Mouthparts: Labrum deeply notched medially (Figure 4C, D); mandible with three dis- tinct dents along the cutting margin and two small blunt dents at the base (Figure $4 \mathrm{E})$.

Thorax: (Figure 5A, C): Prothoracic plate and pre-spiracular plate separate; prothoracic plate with mottled pattern; setae XD1, XD2 and SD1 nearly equidistant from one another; seta SD1 $1.2 \mathrm{x}$ as long as seta XD1 and $3 \mathrm{x}$ that of seta XD2; seta D2 4-5 $x$ as long as seta D1. Seta L1 almost 3.5-4.0 $x$ as long as seta L2; seta SV1 nearly $5 x$ as long as seta SV2; spiracle oval, slightly longer than the length of A1 spiracle; mesothorax and metathorax (Figure 5A): seta D2 nearly $3.5 \mathrm{x}$ as long as seta D1; seta SD1 almost $5 x$ as long as seta SD2; setae L1, L2 and L3 equal in length and each on a separate pinaculum.

Abdomen (Figure 5A-F): Anal plate almondshaped and more convex posteriorly; seta SD1 slightly longer than seta D2, more than $1.5 \mathrm{x}$ as long as seta D1, and 3 or more times as long as seta D3. Ventral prolegs on A3 to 


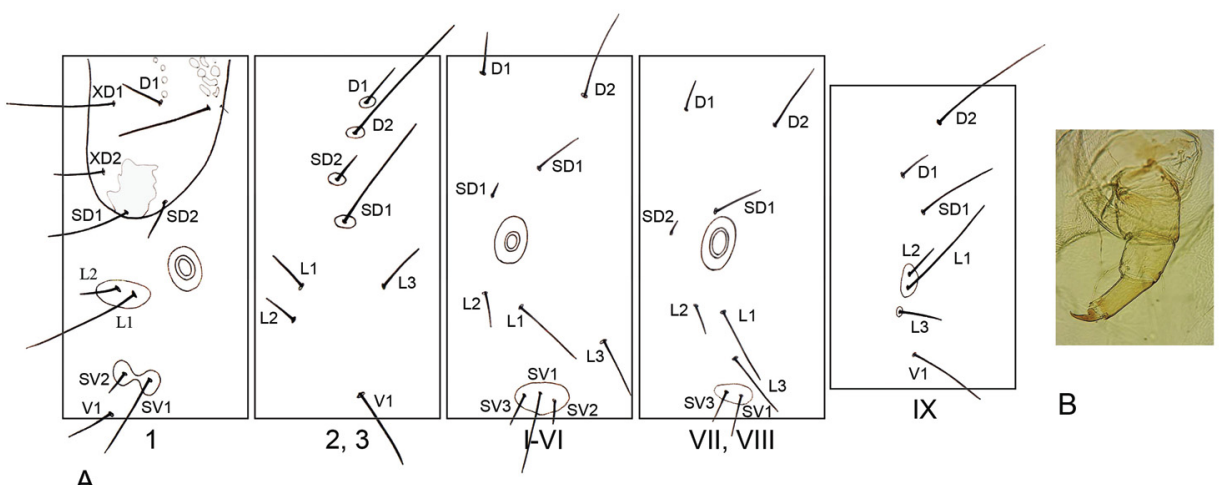

A

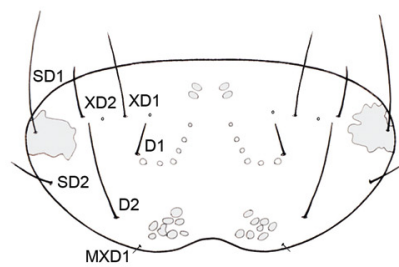

C

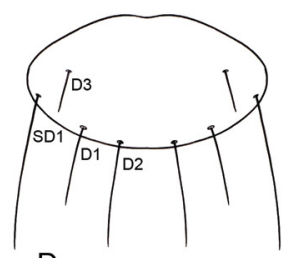

D

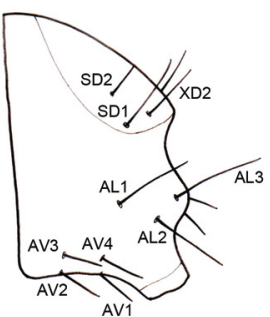

E

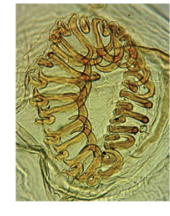

F

Figure 5. Diagrammatic segmental maps of the setae and sclerotizations of thorax and abdomen in the fifth larval instar of Nephopterygia austeritella. A) thoracic (1-3) and abdominal segments (I-IX), B) thoracic leg, C) prothoracic plate, D) anal plate, E) last (X) abdominal segment, F) crochet. Sensillium designations: A, prefix for some anal segments; dorsal, D; lateral, L; supernumary icrodorsal, MXD; subdorsal, SD; subventral, SV; ventral, V; supernumary dorsal, XD.

A6 and A10, crochets uniserial, biordinal, arranged in a complete circle (Figure $5 \mathrm{~F}$ ). In segments A1 to A8: Setae D1 and D2 nearly equidistant; seta D2 more than $2 x$ as long as seta D1; seta SD2 very short compared to SD1; L group trisetose (each in a unique pinaculum). SV group in A1 to A6 trisetose, while in $A 7$ and $A 8$ bisetose (all originate from a common pinaculum). Segment A9: seta D1 dorsal to seta D2; L group trisetose, $L 1$ and $L 2$ very close to each other on a common pinaculum, and $L 3$ on a separate pinaculum; L2 more than $3.5 x$ as long as L1; seta L3 nearly equal in length to seta L1.

\section{Pupa}

Maximum length $6.8 \mathrm{~mm}(\mathrm{n}=8)$; brown, integument almost smooth.

\section{Impact of N. austeritella on P. farcta}

Nephopterygia austeritella larvae consumed $29.6-38.4 \%$ of $P$. farcta pods in the studied areas during 2008-2009 (Table 2). All the seeds along the mesocarp of the pods were completely destroyed (Figure 2E).

\section{Natural enemies of $N$. austeritella}

From a total of 218 larvae of N. austeritella which were collected and reared over two years, 5 parasitized and 14 dead larvae

Table 2. Impact of Nephoterygia austeritella on pods of the Syrian mesquite, $P$. farcta, in central Iran.

\begin{tabular}{l|c|c}
\hline Locality & Year & Damaged pods (\%)* \\
\hline \multirow{2}{*}{ Yazd } & 2008 & 32.3 \\
& 2009 & 36.3 \\
Abarkouh & 2008 & 29.8 \\
& 2009 & 38.4 \\
Darab & 2008 & 29.6 \\
& 2009 & 35.3 \\
\hline
\end{tabular}

* The total number of sampled pods in all cases was 600. 
Table 3. Natural enemies of Nephopterygia austeritella larvae in Yazd, Iran.

\begin{tabular}{l|c|c|c|c|c}
\hline Year & $\begin{array}{c}\text { Nr of } \\
\text { collected } \\
\text { larvae }\end{array}$ & $\begin{array}{c}\text { Nr of } \\
\text { parasitized } \\
\text { larvae }\end{array}$ & $\begin{array}{c}\text { Nr of dead } \\
\text { larvae }\end{array}$ & Mortality (\%) & Natural enemy \\
\hline 2008 & 99 & 3 & ----- & 3.03 & $\begin{array}{c}\text { Apanteles subcamilla } \\
\text { Phanerotoma leucobasis } \\
\text { Phanerotoma leucobasis } \\
\text { Total }\end{array}$ \\
\hline
\end{tabular}

were found (Table 3). The highest mortality (10.92\%) of the larvae was recorded in 2009 due to an unknown factor (internal parasitoid or entomopathogen). Three and two larvae were found to be parasitized in 2008 and 2009, respectively. Two braconid parasitoids, Apanteles subcamilla Tobias and Phanerotoma leucobasis Kriechbaumer were found to parasitize the larvae of N. austeritella (Table 3). An unidentified spider was observed guarding its egg mass near the anaesthetized larva of N. austeritella.

Both parasitoid wasps were gregarious larval ectoparasitoids of $N$. austeritella. Each host larva was attacked by at most six parasitoid larvae in the pods of $P$. farcta. The last larval instar of the parasitoids underwent its pupal stage inside a white cocoon near its host body and the adult wasp emerged in September. These species were responsible for about $1.68-3.03 \%$ of mortality of $N$. austeritella larvae (Table 3).

\section{Discussion}

The present study has revealed for the first time some basic bioecological aspects of $N$. austeritella in its native habitat as a fruit feeding agent of $P$. farcta. This information will be valuable for identifying biological control agents from the genus Prosopis (Johnson, 1983; Mc Kay and Gandolfo, 2007). The life cycle of $N$. austeritella synchronized well with the period of fruit formation of $P$. farcta. The larvae consumed all the seeds and mesocarp of ripening pods of $P$. farcta (Figure $2 \mathrm{E})$. Larval feeding resulted in a destruction of $29.6-38.4 \%$ of the pods of the plant leaving no viable seeds. Considering that each $P$. farcta pod consists of 1-9 seeds, N. austeritella has a larger impact on decreasing the long-lived seed bank of the plant in nature compared with the bruchid beetle, Caryedon angeri which consumes a fraction of the seeds of $P$. farcta (less than 50\%) within a pod (Johnson, 1983; Sertkaya et al., 2005).

Nephopterygia austeritella was the only pyralid moth consuming the ripening pods of $P$. farcta. Pyralids are ecologically important herbivores attacking noxious weeds (McFadyen, 1998; Blossy, 2007; Roe et al., 2015). Seven species of the family Pyralidae have been universally reported targeting reproductive organs of $P$. alba, $P$. glandulosa, $P$. juliflora and $P$. velutina (Beccaloni et al., 2003), six of which occur only in the New World.

As host specificity is one of the most important advantages of a biological control agent (Sheppard et al., 2005; Bourchier et al., 2006; Blossy, 2007), N. austeritella which has been yet only reported on $P$. farcta, can be considered as a promising candidate for biological control of the species of the genus Prosopis. Its closely related genus Nephopterix has a restricted host range to the species of Euphorbia (Cristofaro et al., 1998). In North America, larvae of Nephopterix divisella Duponchel complete their life cycle on seven species, all in the genus Euphorbia. Cristofaro et al. (1998) considered N. divisella as a natural agent against two Euphorbia species namely, E. milii Desmoulins and E. trigona Haworth. Five species of the genus Prosopis are recorded from Iran, where 
$P$. farcta, $P$. koelziana Burkart and $P$. cineraria (Linnaeus) are native and the remaining two species $P$. glandulosa Torrey and $P$. juliflora (Swartz) are introduced (Mozaffarian, 2006; Zare et al., 2011). Prosopis juliflora is a common weed in the south of Iran (NadjafiTireh-Shabankareh and Jalili, 2009). Future studies will reveal the host range and specificity of N. austeritella in Iran.

The Braconid parasitoids, A. subcamilla (Microgaterinae) and Ph. leucobasis (Cheloninae), attack larvae of lepidopteran species (Tobias et al., 1986). Apanteles subcamilla has been only reported from Azerbaijan without any host record but Ph. leucobasis is known from Egypt, Ethiopia, Kenya, Madagascar, Nigeria, S.W. Africa, Saudi Arabia, Socotra island (Yemen), Somalia, Tanzania, Togo and Iran (Ameri et al., 2012; Gadallah and Ghahari, 2013) with a wide range of hosts in the families Cosmopterygidae, Pyralidae and Gelechidae (Van Achterberg, 1990; Sobhani et al., 2012; Yu et al., 2012). Based on the literature, associations of these parasitoid species with $N$. austeritella and $P$. farcta are new.

Egg and pupal parasitoids of $N$. austeritella were not detected in the study, although they may be attacked by hymenopterous parasitoids (Triplehorns and Johnson, 2005). Thus, an intensive or longer period of field surveying is required to improve our knowledge of natural enemies of $N$. austeritella (Blossy, 2007). Parasitoids and other factors were responsible for the mortality of $N$. austeritella individuals during 2008 and 2009 (Table 3). Mortality factors in biological control agents of weeds have been regarded as a threat (Zalucki and Van Klinken, 2006; Zachariades et al., 2011). The rate of larval parasitism of Caryedon angeri, a bruchid seed-beetle of $P$. farcta, by Rhaconotus major (Hym.: Braconidae) in Turkey varied from 62.3-100\% (Sertkaya et al., 2005). Parasitism of larvae and pupae of Melipotis indomita Walker (Lep.: Noctuidae), a biological control agent of $P$. glandulosa, was considered as an important mortality factor affecting $M$. indomita population (Cuda et al., 1990). The low rate of larval parasitism of $N$. austeritel- la may be due to the fact that moth larvae are concealed in the pods of $P$. farcta and remain less vulnerable to the attack by parasitoids (Hill and Hulley, 1995; Van Klinken and Burwell, 2005).

N. austeritella could be used as a potential biological control agent in an integrated pest management program against $P$. farcta. Further studies would be necessary to evaluate different aspects of the biology, demography, behavior, host specificity of $N$. austeritella and its possible impact on native plants and other species of the genus Prosopis in Iran and neighboring countries (McFadyen, 1998; Bourchier et al., 2006; Blossy, 2007).

This study was supported by Shiraz University, Iran. We express our gratitude to Dr W. Gerald Tremewan (Truro, U.K.) and Dr Mehrdad Parchami-Araghi for kindly checking the original manuscript. We also thank Shirin Roohigohar (Islamic Azad University, Science and Research Branch, Tehran, Iran) for preparing the distribution map.

\section{Literature cited}

Alipanah H., Asselbergs J. and Sarani M. 2012. Redescription of Nephopterygia austeritella Amsel, 1965 (Pyralidae: Phycitinae) with description of its hitherto unknown female. Nota Lepidopterologica, 35: 185-191.

Ameri A., Talebi A., Kamali K. and Rakhshani E. 2012. Study of the tribe Phanerotomini Baker (Hymenoptera: Braconidae) in Hormozgan province of Iran with two new records. Biosystematica, 6: 31-38.

Amsel H.G. 1965. Ergebnisse der Zoologischen Nubien Expedition 1962. Teil XXIX . Lepidoptera: Pyralidae, Pterophoridae. Annalen Naturhistorisches Museum Wien, 68: 593-607.

Anton K.W. and Delobel A. 2004. Description of five new species in the genus Caryedon Schoenherr, with a taxonomical note on C. angeri (Semenov) (Coloptera: Bruchidae: Pachymerinae). Genus, 15: 65-90.

Asselbergs J. 2009. New data for Pyraloidea from Fuerteventura (Canary Islands, Spain) including a species new to Science (Lepidoptera: Pyraloidea). SHILAP Revista de Lepidopterología, 405-420.

Atomov V. and Aktoklu E. 2007. Productivity and 
phytosociological properties of steppe pastures on the Amic plain (Hatay, Turkey). Russian Journal of Ecology, 38: 436-439.

Bagheri-Zenous E. 1992. The groundnut seed beetle (Caryedon palaestinicus Stout. Coleóptera: Bruchidae) a new pest in Iran. Iranian Journal of Agricultural Science, 26: 65-69.

Bazzaz F.A. 1973. Seed germination in relation to salt concentration in three populations of Prosopis farcta. Oecologia, 13: 73-80.

Beccaloni G., Scoble M., Kitching I., Simonsen T., Robinson G., Pitkin B., Hine A. and Lyal C. 2003. The Global Lepidoptera Names Index (Leplndex). World Wide Web electronic publication. London, Uk: Natural History Museum.

Bisby F.A., Roskov Y.R., Orrell T.M., Nicolson D., Paglinawan L.E., Bailly N., Kirk P.M., Bourgoin T., Baillargeon G. and Ouvrard D. 2011. Species 2000 \& ITIS Catalogue of Life: 2011 Annual Checklist.

Blossy B. 2007. Biological control of weeds using arthropods. In Upadhyaya M. et al. (eds). Nonchemical Weed Management: Priciples, Concepts and Technology. Oxfordshire, UK: CAB International, p. 77-92.

Bourchier R.S., Hansen R., Lym R., Norton A., Olson D., Randall C.B., Schwarzlander M. and Skinner L. 2006. Biology and biological control of leafy spurge. US Department of Agriculture, Forest Service, FHTET, p.

Canadell J., Jackson R., Ehleringer J., Mooney H., Sala O. and Schulze E.D. 1996. Maximum rooting depth of vegetation types at the global scale. Oecologia, 108: 583-595.

Cristofaro M., Sale F., Campobasso G., Knutson L. and Sbordoni V. 1998. Biology and Host Preference of Nephopteryx divisella (Lepidoptera: Pyralidae): Candidate Agent for Biological Control of Leafy Spurge Complex in North America Environmental Entomology, 27: 731-735.

Cuda J., DeLoach C. and Robbins T. 1990. Population dynamics of Melipotis indomita (Lepidoptera: Noctuidae), an indigenous natural enemy of mesquite, Prosopis spp. Environmental entomology, 19: 415-422.

Dogan Y., Baslar S., Ay G. and Mert H.H. 2004. The use of wild edible plants in Western and Central Anatolia (Turkey). Economic Botany, 58: 684-690.

Esmailzadeh-Hosseini S.A., Salehi M. and Mirzaie A. 2011. Alternate hosts of alfalfa witches' broom phytoplasma and winter hosts of its vector Orosius albicinctus in Yazd-Iran. In Proceedings of the Bulletin of Insectology, p. S247-S248.

Freitas A.V.L. 1993. Biology and population dynamics of Placidula euryanassa, a relict ithomiine butterfly(Nymphalidae: Ithomiinae). Journal of the Lepidopterists Society, 47: 87-105.

Fterich A., Mahdhi M., Caviedes M., Pajuelo E., Rivas R., Rodriguez-Llorente I. and Mars M. 2011. Characterization of root-nodulating bacteria associat- ed to Prosopis farcta growing in the arid regions of Tunisia. Archives of Microbiology, 193: 385-397.

Gadallah N.S. and Ghahari H. 2013. An annotated catalogue of the Iranian Cheloninae (Hymenoptera: Braconidae). Linzer Biologische Beitrage, 45: 1921-1943.

Godfrey G.L. 1972. The last larval instar of Lithacodia albidula (Lepidoptera: Noctuidae). Journal of the Kansas Entomological Society, 45: 427-430.

Hasenfuss I. and Kristensen N.P. 2003. Skeleton and muscles: immatures. In Kristensen N.P. (eds). Lepidoptera, Moths and Butterflies. vol. 2: Morphology, Physiology, and Development. Handbook of Zoology. IV Insecta. Berlin, New York: Walter de Gruyter, p. 133-164.

Hill M.P. and Hulley P.E. 1995. Host-range extension by native parasitoids to weed biocontrol agents introduced to south africa. Biological Control, 5:

Johnson C.D. 1983. handbook on seed insects of Prosopis species: Ecology, Control, and Identification of Seed-infesting Insects of New World Prosopis (Leguminosae). Rome, Italy: Food and Agricultural Organization of the United Nations, $43 \mathrm{p}$.

Mc Kay F. and Gandolfo D. 2007. Phytophagous insects associated with the reproductive structures of mesquite (Prosopis spp.) in Argentina and their potential as biocontrol agents in South Africa. African Entomology, 15: 121-131.

McFadyen R.E.C. 1998. Biological control of weeds. Annual Review of Entomology, 43: 369-393.

Mozaffarian V. 2006. A dictionary of Iranian plant names: Latin, English, Persian. Tehran, Iran: Farhang Mo'aser, $596 \mathrm{p}$.

Nadjafi-Tireh-Shabankareh K. and Jalili A. 2009. Comparison of vegetation cover under canopy cover and open area of Prosopis juliflora (SW.)DC in Hormozgan province. Pajouhesh \& Sazandegi, 80: 176-184.

Omidi A., Ansari nik H. and Ghazaghi M. 2012. Prosopis farcta beans increase HDL cholesterol and decrease LDL cholesterol in ostriches (Struthio camelus). Tropical Animal Health and Production, 1-4.

Pasiecznik N., Harris P., Smith S. and Association H.D.R. 2004. Identifying tropical Prosopis species: a field guide. HDRA Publishing, $30 \mathrm{p}$.

Qasem J.R. 2007. Chemical control of Prosopis farcta (Banks and Sol.) Macbride in the Jordan Valley. Crop Protection, 26: 572-575.

Roe A.D., Simonsen T.J., Scholtens B., Sperling F.A.H. and Weller S.J. 2015. Phycitinae phylogeny based on two genes, with implications for morphological trait evolution and Heinrich's tribal classification (Lepidoptera: Pyralidae). Journal of the Lepidopterists' Society, 69: 157-172.

Said O., Khalil K., Fulder S. and Azaizeh H. 2002. Ethnopharmacological survey of medicinal herbs in Israel, the Golan Heights and the West Bank region. Journal of Ethnopharmacology, 83: 251265. 
Sertkaya E., Uremis I. and Yigit A. 2005. Natural Efficiency of Caryedon palaestinicus Southgate (Coleoptera, Bruchidae; Pachymerinae) Feeding on the Seeds of Mesquit, Prosopis farcta (Banks and Sol.) Macbride. Pakistan Journal of Biological Sciences, 8: 85-88.

Sheppard A.W., Van Klinken R.D. and Heard T.A. 2005. Scientic advances in the analysis of direct risks of weed biological control agents to nontarget plants. Biological Control, 35: 215-226.

Sobhani M., Goldansaz S.H. and Hatami B.P.o., 83. 2012. Study of larval parasitoids of carob moth Ectomyelois ceratoniae (Lep.: Pyralidae) in Kashan region. In Proceedings of the 20th Iranian Plant Protection Congress, Shiraz, Iran, 25-28. Aug.2012, p. 83.

Tobias V., Belokobylskij S. and Kotenko A. 1986. Family Braconidae, Keys to the Insects of the European Part of the USSR, III. Part V. Leningrad: Nauca Publisher, $908 \mathrm{p}$.

Triplehorns C.A. and Johnson N., F. 2005. Borror and Delong's Introduction to the study of insects. United states: Thomson Brooks/Cole, $879 \mathrm{p}$.

Van Achterberg C. 1990. Revision of the western Palaearctic Phanerotomini (Hymenoptera: Braconidae). Zoologische Verhandelingen (Leiden), 255: 1-106.

Van Klinken R.D. and Burwell C.J. 2005. Evidence from a gelechiid leaf-tier on mesquite (Mi- mosaceae: Prosopis) that semi-concealed Lepidopteran biological control agents may not be at risk from parasitism in Australian rangelands. Biological Control, 32: 121-129.

Yu D.S., Van Achterberg K. and Horstmann K. 2012. World Ichneumonoidae 2011. Taxonomy, Biology, Morphology and Distribution. Ottawa, Ontario, Canada: Taxapad.com.

Zachariades C., Hoffmann J. and Roberts A. 2011. Biological control of mesquite (Prosopis species) (Fabaceae) in South Africa. African Entomology: Biological control of invasive alien plants in South Africa (1999-2010): Special Issue 2, 19: 402-415.

Zalucki M.P. and Van Klinken R.D. 2006. Predicting population dynamics of weed biological control agents: science or gazing into crystal balls? Australian Journal of Entomology, 45: 331-344.

Zare S., Tavili A. and Darini M.J. 2011. Effects of different treatments on seed germination and breaking seed dormancy of Prosopis koelziana and Prosopis Juliflora. Journal of Forestry Research, 22: 35-38.

Received: 10 November 2015; Accepted: 7 June 2016

\title{
Bı--окодорía tou Nephopterygia austeritella (Lep.: Pyralidae),

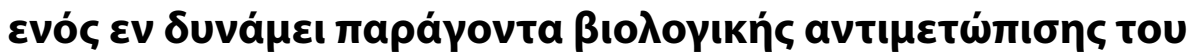

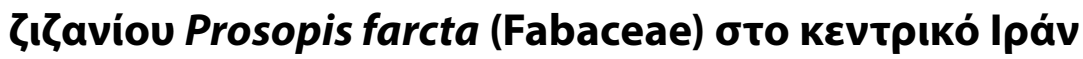

\author{
A. Mohammadi-Khoramabadi, H. Alipanah, S. Belokobylskij and M.R. Nematollahi
}

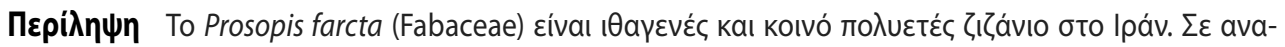

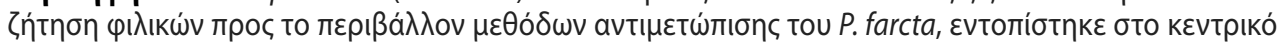

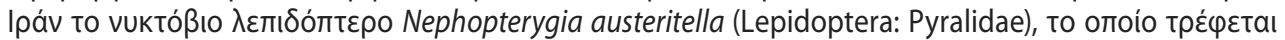

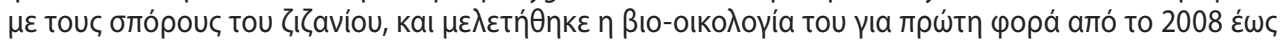

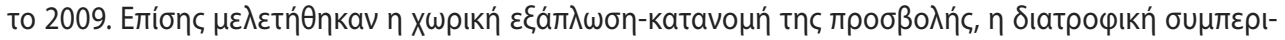

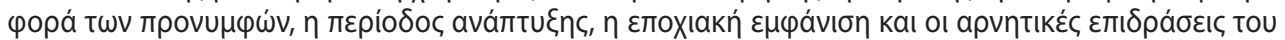

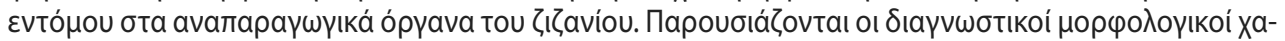

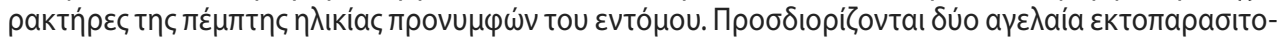

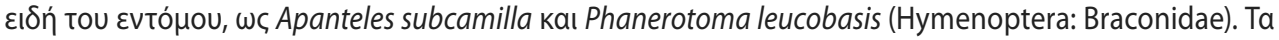

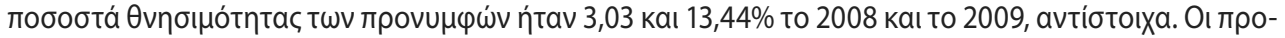

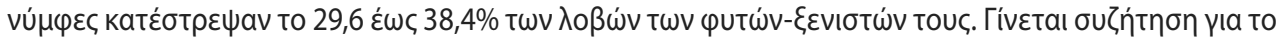

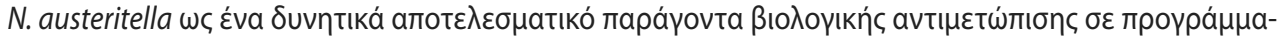

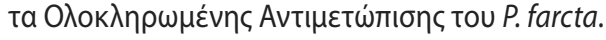

Hellenic Plant Protection Journal 9: 78-88, 2016 